\title{
EGFR unusual mutation status in lung adenocarcinomas
}

\author{
Ana Alarcão ${ }^{1,2^{*}}$, Vitor Sousa ${ }^{1,2,3,4}$, Patrícia Couceiro ${ }^{1,2}$, Maria Silva ${ }^{1,2,3}$, Maria J d'Aguiar ${ }^{1}$, Lia Teixeira ${ }^{1}$, \\ Lina Carvalho $1,2,3,4$ \\ From 16th International Charles Heidelberger Symposium on Cancer Research \\ Coimbra, Portugal. 26-28 September 2010
}

Lung cancer is the most common cause of cancer deaths in both men and women. Adenocarcinoma represents about $28 \%$ of the NSCLC cases in men and $42 \%$ in women. EGFR is a member of the ERBB family of tyrosine kinases (TK). EGFR mutations are more frequently observed in female, non-smokers, East-Asian and in patients with adenocarcinomas, and predict response to TK Inhibitors (TKIs).

Sections of adenocarcinomas of the lung, formalinfixed paraffin-embedded tissues (FFPE), were selected to analyze mutations in EGFR exons 19 and 21 by DNA extraction for polymerase chain reaction (PCR). Exon 19 was studied by fragment analysis and exon 21 was studied by direct sequencing. The analysis of FISH results was done by Cappuzzo's score to EGFR gene. Determination of EGFR protein expression was done by immunohistochemistry (IHC) (Zymed Laboratories).

The author's present two cases of lung adenocarcinoma that harbours coexisting EGFR exon 19 and 21 mutations and one case of EGFR multiple in framedeletions. The patients were female $(n=3)$, with mixed type adenocarcinoma overexpressing EGFR by IHC.

Most reports demonstrate one EGFR mutation per adenocarcinoma. We demonstrated that a single adenocarcinoma can harbour more than one EGFR activating mutations.

\section{Author details}

${ }^{1}$ Instituto de Anatomia Patológica - Faculdade de Medicina da Universidade de Coimbra, Coimbra, Portugal. ${ }^{2}$ Centro de Investigação em Meio Ambiente, Genética e Oncobiologia, Coimbra, Portugal. ${ }^{3}$ Centro de Pneumologia Faculdade de Medicina da Universidade de Coimbra, Coimbra, Portugal.

\footnotetext{
* Correspondence: amalarcao@fmed.uc.pt

${ }^{1}$ Instituto de Anatomia Patológica - Faculdade de Medicina da Universidade de Coimbra, Coimbra, Portugal

Full list of author information is available at the end of the article
}

${ }^{4}$ Serviço de Anatomia Patológica dos Hospitais da Universidade de Coimbra, Coimbra, Portugal.

Published: 24 September 2010

doi:

Cite this article as: Alarcão et al:: EGFR unusual mutation status in lung adenocarcinomas. BMC Proceedings 2010 4(Suppl 2):P61.
Submit your next manuscript to BioMed Central and take full advantage of:

- Convenient online submission

- Thorough peer review

- No space constraints or color figure charges

- Immediate publication on acceptance

- Inclusion in PubMed, CAS, Scopus and Google Scholar

- Research which is freely available for redistribution

Submit your manuscript at www.biomedcentral.com/submit
C Biomed Central 